\title{
Predisposing factors influencing occupational injury among frontline building construction workers in Ghana
}

\author{
John Amissah ${ }^{1 *}\left(\mathbb{0}\right.$, Eric Badu ${ }^{3}$, Peter Agyei-Baffour ${ }^{1}$, Emmanuel Kweku Nakua ${ }^{2}$ and Isaac Mensah ${ }^{4}$
}

\begin{abstract}
Objective: This study aims to examine the predisposing factors influencing occupational injuries among frontline construction workers in Ghana. A cross-sectional survey was carried out with 634 frontline construction workers in Kumasi metropolis of Ghana using a structured questionnaire. The study was conducted from December 2016 to June 2017 using a household-based approach. The respondents were selected through a two-stage sampling approach. A multivariate logistics regression model was employed to examine the association between risk factors and injury. Data was analyzed employing descriptive and inferential statistics with STATA version 14.

Results: The study found an injury prevalence of 57.91\% among the workers. Open Wounds (37.29\%) and fractures (6.78\%) were the common and least injuries recorded respectively. The proximal factors (age, sex of worker, income) and distal factors (e.g. work structure, trade specialization, working hours, job/task location, and monthly off days) were risk factors for occupational injuries among frontline construction workers. The study recommends that policymakers and occupational health experts should incorporate the proximal and distal factors in the design of injury prevention as well as management strategies.
\end{abstract}

Keywords: Occupational Injury, Kumasi, Ghana, Prevalence, Frontline construction workers

\section{Introduction}

An occupational injury is described as any personal injury, disease or death that results from an occupational accident [1]. Globally, occupational injury has been identified as the leading cause of industrial ailment accounting for over $11 \%$ of disability [2-4]. Consistently, estimates suggest that over 350,000 people globally suffer from workplace injuries $[5,6]$. Reporting information on occupational injuries is essential to assess the extent to which workers are protected from work-related hazards and risks [7].

Several studies and theories have been employed to explain the factors that influence occupational injuries. Generally, the constrain-response accident model has

\footnotetext{
*Correspondence: pinnochkio@gmail.com

${ }^{1}$ Department of Health Policy, Management and Economics, School of Public Health, Kwame Nkrumah University of Science and Technology, Kumasi, Ghana

Full list of author information is available at the end of the article
}

widely been used in the construction literature [8]. The theory suggests that each individual at the workplace plays a unique role and in the course of executing those roles is constrained by certain factors and their response to these constrain also create an additional set of constrain for other participants who depend on the formal's actions to act $[8,9]$. In particular, occupational injury is seen as a product of the interaction between management, organizational and operational features. This theory is explained according to two main constructs, namely proximal and distal factors $[8,9]$. It argued that certain deficiencies in institutional activities could trigger an employee's action that could lead directly or indirectly to an occurrence of an accident and eventually to an injury [10-17]. Those deficient factors that directly increase an individual's risk to an accident are known as the proximal factors. These proximal factors do not predict that occupational injury will definitely happen, but rather indicates that a worker may be at risk of occupational injury at some time in the future $[8,9]$. 
The distal factors, on the other hand, are managerial or organizational constrain experienced by employees and their responses to those constraints. They are those factors that could lead, with inappropriate response/action from employees indirectly to increasing the risk of accident causation as a result of the presence of the proximal factors [18]. The distal variables highlight organizational factors (e.g., management, organization and operation) that makes the individual vulnerable for an occupational injury. The distal factors which can increase the risk of occupational injuries are overtime measures, production target, number of working hours, type of work structure, income and task location [8-17]. Conversely, the proximal factors may include immediate individual lifestyle characteristics (e.g. alcohol consumption, smoking, adherence to safety regulation, type of work and exposure to hazards) and socio-demographic profile (e.g. age, gender, work experience) $[13,19]$. More specifically, the distal factors lead to the introduction of proximal factors, whereas the proximal factors lead to the accident causation with injury as one of the final outcomes [11, 14].

In Ghana, occupational injuries have been identified among the leading causes of death. Specifically, 56 out of 902 occupational accidents reported in the year 2000 were from construction-related injuries [20]. This calls for government policies and interventions regarding occupational injuries in the construction industry. Despite this, little is known about the predictive factors that contribute to the burden of occupational injuries among construction workers. The few empirical studies measuring the prevalence and risk factors on injuries are limited to mining [21], domestic setting [3], transportation and manufacturing industries [22, 23], with little or no attention on building construction [17, 24, 25]. To our knowledge, no study has measured factors influencing occupational injuries among construction workers. Therefore, this paper aims to contribute to this gap by exploring the prevalence and predisposing factors influencing occupational injuries among frontline construction workers in Ghana.

\section{Main text}

\section{Methodology}

A cross-sectional design was employed to collect data from frontline building construction workers from December 2016 to June 2017. The study was limited to building construction workers in the Kumasi Metropolis of Ghana. Kumasi metropolis was selected due to its cosmopolitan nature, heterogeneous population and economic activities with distinct cultural enclaves making it a representation of the behaviour of building construction workers in Ghana [26]. The study recruited workers aged between 15 and 64 years who were actively engaged in construction activities for at least 12 calendar months. The workers were limited to carpenters, masons, brick/ block layers, steel benders, and laborers. A sample size of 635 workers was estimated using Cochrane formulae $[27,28]$. An assumed prevalence of $50 \%$ injuries in the construction industry with a precision of $5 \%$, a design effect of $1.5 \%$ and non-response of $10 \%$ were used to estimate the sample size. A multi-stage sampling method was used to select respondents. The first stage involved selecting ten sub-metro in Kumasi metropolis. A simple random sampling was employed to select participants from households in the communities located in each sub-metro.

\section{Data collection}

Data were obtained through the administration of structured questionnaires on a face-to-face basis. The variables used in the questionnaire were identified from previous literature, theories, and standard injury questionnaire. A questionnaire template was developed and loaded onto a smartphone with ODK (Open Data kit) [29, 30]. The interviews were conducted in the respondent's preferred dialect (e.g. mostly Asante Twi) [22]. Research assistants were trained on the use of ODK data collection software. Written informed consent was obtained from all participants enrolled in this study and identities of participants were kept anonymous. Consent was also sought from caretakers and parents of minor workers below 18 years who were actively involved in construction work. The questionnaire was pre-tested at Ejisu-Juaben Municipality, to check its reliability. The weakness identified was effected on the final questionnaire.

\section{Data analysis}

The data were summarized using descriptive and inferential statistics. Multivariate Logistics regression analysis was employed to identify the predisposing factors influencing occupational injuries. The injury was operationalized as all physical harm or damage to a person's body caused by an object $[1,15]$. The dependent variable was an injury sustained by a worker and the independent variables were individual factors such as demographic, socio-economic, job conditions, alcohol consumption, overtime and rest time. Data were analyzed using STATA 14 , the significant level was maintained at a $P$ value $\leq 0.05$ and presented at $95 \%$ confidence interval. All monetary values were converted from the Ghanaian cedis (GHS) to the United States dollar (US\$) equivalence using the prevailing exchange rate of GHS 4.2765: 1 US \$ as published central bank of Ghana [31]. 


\section{Results}

The mean age of the workers was $31.43 \pm 8.9$ years, the majority were males (89.3\%) and married (58.8\%). About 53.3\% had basic level education and $22.5 \%$ had no formal education. The years of working experience were $7.57 \pm 7.4$. About $44.4 \%$ worked as daily paid workers, $17.6 \%$ as permanent and $37.9 \%$ as temporal workers. More than half were labourers (56.2\%). Fifty percent earned a monthly income of GHS 960.0 (US $\$=224.5$ ) (Table 1).

\section{The prevalence and types of occupational injuries}

The injury prevalence among the frontline construction workers was $57.9 \%$. About $37.3 \%$ experienced open wound, superficial (on surface) (15.3\%), concussion and internal injuries (15.3\%), dislocation and sprains (10.5\%), traumatic amputation and deformity (8.5\%), fractures $(6.8 \%)$ and $6.5 \%$ suffered from other injuries (Table 2).

\section{The predictors of occupational injuries}

In the multivariate analysis, covariates such as age, sex, type of work structure, income, trade specialization, working hours, job location and monthly off-days were statistically significant predictors of injury (Table 3 ).

Workers between ages 25-34 were [aOR $=0.41 ; 95 \%$ $\mathrm{CI}=0.20,0.80$ ] less likely to be exposed to the risk of injury than those below 24 years. The male workers were more likely to experience injury $[\mathrm{aOR}=6.07$; 95\% CI $=2.41-15.29]$ compared to females. Consistently, workers who engaged permanently $[\mathrm{aOR}=3.97$; 95\% CI. $=1.93-8.17$ and temporal basis $[\mathrm{OR}=2.03$; $95 \%$ CI. $=1.25-3.31]$ were more likely to experience an injury than those working on daily basis. High income workers above GHS 1000 (US \$ 233.87) [aOR=3.52; 95\% CI. $=0.98-12.64$ ] and GHS 1500 (US \$ 350.83) $[\mathrm{aOR}=22.63 ; 95 \% \mathrm{CI} .=1.60-320.51]$ were more likely to be exposed to injury than low income workers. Steel Bender/Fixers were $78 \%$ protected from injury $[\mathrm{aOR}=0.22 ; 95 \% \mathrm{CI}=0.07-0.64]$ compared with other trade specialization. Similarly, Risk was reduced by $95 \%$ $[\mathrm{aOR}=0.05 ; 95 \% \mathrm{CI}=0.02-0.15]$ and $84 \%[\mathrm{aOR}=0.16$; $95 \% \mathrm{CI}=0.04-0.36]$ for workers working between 4-6 $\mathrm{h}$ and 7-9 h daily compared to those working above $10 \mathrm{~h}$. Also, workers operating from all location at the workplace could avert injury by $71 \%$ [aOR $=0.29 ; 95 \%$ $\mathrm{CI}=0.85-1.01]$ compared to working on rooftops and from height. Workers who were entitled to off-days were 96\% protected from the possibility of experiencing injury $[\mathrm{aOR}=0.96 ; 95 \% \mathrm{CI}=0.04-0.24]$ compared to those without off-days.
Table 1 Demographic characteristics

\begin{tabular}{|c|c|c|}
\hline Characteristics & Frequency $(n=634)$ & Percentage \\
\hline \multicolumn{3}{|l|}{ Age group } \\
\hline $15-24$ years & 143 & 22.5 \\
\hline $25-34$ years & 298 & 46.8 \\
\hline $35-44$ years & 136 & 21.5 \\
\hline $45+$ year & 57 & 9.3 \\
\hline Mean (SD) & $31.43(8.85)$ & \\
\hline \multicolumn{3}{|l|}{ Sex } \\
\hline Male & 569 & 90.0 \\
\hline Female & 63 & 9.9 \\
\hline \multicolumn{3}{|l|}{ Marital status } \\
\hline Single & 262 & 41.1 \\
\hline Married & 375 & 58.8 \\
\hline \multicolumn{3}{|l|}{ Educational level } \\
\hline No Formal education & 143 & 22.5 \\
\hline Basic education $^{a}$ & 341 & 53.3 \\
\hline High school & 137 & 21.5 \\
\hline Tertiary $^{b}$ & 16 & 2.5 \\
\hline \multicolumn{3}{|l|}{ Working experience (years) } \\
\hline $1-4$ years & 304 & 47.7 \\
\hline $5-9$ years & 143 & 22.5 \\
\hline $10-20$ years & 157 & 24.6 \\
\hline $21+$ & 33 & 5.2 \\
\hline Mean SD & $7.57(7.40)$ & \\
\hline \multicolumn{3}{|l|}{ Work structure } \\
\hline Daily paid worker (by day work) & 283 & 44.4 \\
\hline Temporal workers & 242 & 37.9 \\
\hline Permanent worker & 111 & 17.6 \\
\hline \multicolumn{3}{|l|}{ Monthly income in GHS [US\$] } \\
\hline $360-499$ [84.2-116.7] & 19 & 2.9 \\
\hline $500-999[116.9-233.6]$ & 389 & 61.1 \\
\hline $1000-1499$ [233.8-350.5] & 204 & 32.0 \\
\hline $1500+[350.8]$ & 25 & 3.9 \\
\hline Average income in GHS (SD) & \multicolumn{2}{|c|}{$954.86[223.3] \pm 311.89[72.9]$} \\
\hline Median [US \$] & \multicolumn{2}{|l|}{$960[224.5]$} \\
\hline $\begin{array}{l}\text { Average wage }[U S \$] \pm S D \text { per } \\
\text { Artisan }\end{array}$ & \multicolumn{2}{|c|}{ Median [US\$] wage per Artisan } \\
\hline Mason & $60[14.0] \pm 22.8[5.3]$ & $50[11.7]$ \\
\hline Labourer & $33.70[7.9] \pm 6.3[1.5]$ & $30[7.0]$ \\
\hline Carpenter & $52.86[12.4] \pm 12.9[3.0]$ & $60[14.0]$ \\
\hline Steel bender & $46.31[10.8] \pm 10.8[2.5]$ & $50[11.7]$ \\
\hline $\begin{array}{l}\text { Average wage per artisans [US } \\
\$] \pm S D\end{array}$ & \multicolumn{2}{|l|}{$40.65[9.5] \pm 13.0[3.0]$} \\
\hline \multicolumn{3}{|l|}{ Trade specialization } \\
\hline Mason & 176 & 27.6 \\
\hline Labourer & 358 & 56.2 \\
\hline Carpenter & 70 & 10.9 \\
\hline Steel bender & 33 & 5.1 \\
\hline
\end{tabular}

GHS 4.2765: US\$ 1

a Basic education: nine-year training from primary one to completion junior high school and Middle School

b Tertiary education: includes University and Polytechnics 
Table 2 Body regions, injury types and frequencies

\begin{tabular}{|c|c|c|}
\hline Variable & Frequency & Percentage \\
\hline \multicolumn{3}{|l|}{ Injury experience in last 12 months } \\
\hline Yes & 355 & 57.9 \\
\hline No & 258 & 42.0 \\
\hline \multicolumn{3}{|l|}{ Type of injury } \\
\hline Fracture & 24 & 6.7 \\
\hline Open wound & 132 & 37.3 \\
\hline Dislocation and sprains & 37 & 10.5 \\
\hline Superficial (on surface) injury & 54 & 15.3 \\
\hline Concussion and internal injury & 54 & 15.3 \\
\hline Traumatic amputation and deformity & 30 & 8.5 \\
\hline Other specific injuries ${ }^{a}$ & 23 & 6.5 \\
\hline
\end{tabular}

a Other specific Injuries: All those including effects of heat, electric shocks, physical and psychological abuses, multiple injuries without specific description

\section{Discussion}

The study adds to the existing literature, as the findings are discussed using the constraint-response accident model. The constructs used to organize the discussion are (1) prevalence and type of occupational injuries, (2) proximal factors predicting occupational injuries and (3) distal factors influencing occupational injuries.

\section{The prevalence and type of injuries sustained}

The study showed that more than half, (57.9\%) of construction workers had experienced occupational injuries. The prevalence appears to be higher when compared to previous estimates elsewhere [32]. Even though there are no nationally representative data on the extent of injuries sustained by construction workers, the current prevalence is about 9.3 times higher than previous reports by the labour commission, which estimated that $6.2 \%$ of occupational accidents lead to deaths in construction [20]. Of relevance, the present finding demonstrates an increasing burden of injuries among workers. This confirms previous literature in Ghana and Europe which reported the industry to be injury-prone [17, 24, 25]. Specifically, injuries sustained by the workers were open wounds, superficial (on surface) and concussion and internal injury. These injuries are similar to the categories of injuries reported to be sustained by construction workers globally [33-38]. The study recommends that policymakers and occupational health experts should develop preventive and management strategies that incorporate specific injury part sustained. Also, future research should employ interventional studies to measure the effectiveness of preventive strategies for managing occupational injuries among construction workers. This could inform regulatory authorities to improve their health education and promotion campaigns.

\section{Proximal factors predicting of occupational injuries}

The proximal factors influencing occupational injuries highlight the immediate individual lifestyle characteristics (e.g. alcohol consumption, smoking, adherence to safety regulation, type of work and exposure to hazards) and socio-demographic profile. These factors had a relationship with occupational injuries. In this study, the socio-demographic profile such as age, sex, and income significantly predicted occupational injuries among construction workers. In particular, males were at high risk of being injured compared with females. In Ghana, the socio-cultural characteristics restrict the construction activities to males. This is due to the rigorous and hazardous nature of the construction industry [39]. Therefore, female workers are recommended to be placed in roles with limited risk in the industry. In addition, the income level of construction workers is a significant risk factor for occupation injury. Tasks with a high risk of injury usually require an expert to execute. However, in performing such duties, the worker's exposure to such risk becomes higher which may eventually translate to injuries compared to other workers assigned to simple tasks. In Ghana, construction workers with this technical expertise are usually short in supply and also demand relatively higher wages than those doing menial and causal works. This possibly explains why workers in this category were at higher risk of occupational injury.

In addition, the risk of occupational injury increased with older workers compared to the youthful age group (economic active population). Older workers are susceptible to severe injury than younger ones [32, 40-42]. Aging process involves a series of physiological changes to the body that can make construction tasks very difficult for old people. The strength and ability required of a person to carry out physically demanding tasks effectively reduce as one age. Decrease cardiac output may affect a worker's performance on physical demanding activity and increase his susceptibility to injury [43]. The study recommends stakeholders to consider the age profile, gender identity and socioeconomic status of construction workers when designing preventive and management strategies for injuries. In particular, future research should use a longitudinal approach to report a national representative data on occupational injuries among frontline construction workers. This can inform government policy and interventions. Further, researchers interested in occupational health-related issues should explore the reasons for the increased occupational injuries among different age, gender, and socio-economic wealth quintiles. For instance, future research should used a qualitative methods to explore the subjective experiences of frontline construction workers in managing occupational injuries. 
Table 3 Univariate and multivariate analysis of risk factors for occupational injuries among frontline building construction workers in Ghana, 2016/17

\begin{tabular}{|c|c|c|c|c|}
\hline \multirow[t]{2}{*}{ Variables } & \multicolumn{2}{|l|}{ Univariate model } & \multicolumn{2}{|l|}{ Multivariate model } \\
\hline & $\begin{array}{l}\text { Crude odd ratio (OR; } 95 \% \\
\text { Cl) }\end{array}$ & P-value & $\begin{array}{l}\text { Adjusted odd ratio (aOR; } \\
95 \% \mathrm{Cl} \text { ) }\end{array}$ & P-value \\
\hline \multicolumn{5}{|l|}{ Age group } \\
\hline $15-24$ years (ref) & 1.00 & - & 1.00 & - \\
\hline $25-34$ years & $0.77(0.51,1.16)$ & 0.21 & $0.41(0.20,0.80)$ & 0.009 \\
\hline $35-44$ years & $1.04(0.64,1.69)$ & 0.88 & $0.53(0.19,1.44)$ & 0.21 \\
\hline $45+$ year & $2.48(1.20,5.13)$ & 0.01 & $0.78(0.23,2.63)$ & 0.68 \\
\hline \multicolumn{5}{|l|}{ Sex of worker } \\
\hline Female (ref) & 1.00 & - & 1.00 & - \\
\hline Male & $5.51(2.90,10.45)$ & 0.001 & $6.07(2.41,15.29)$ & 0.001 \\
\hline \multicolumn{5}{|l|}{ Marital status } \\
\hline Single (ref) & 1.00 & - & - & - \\
\hline Married & $1.25(0.91,1.73)$ & 0.18 & - & - \\
\hline \multicolumn{5}{|l|}{ Educational level } \\
\hline No formal education ref & 1.00 & - & - & - \\
\hline Basic education & $0.65(0.42,0.99)$ & 0.04 & - & - \\
\hline High school & $0.61(0.36,1.03)$ & 0.06 & - & - \\
\hline Tertiary & $0.75(0.27,2.14)$ & 0.60 & - & - \\
\hline \multicolumn{5}{|l|}{ Working experience (years) } \\
\hline $1-4$ years & $0.23(0.09,0.56)$ & 0.001 & - & - \\
\hline $5-9$ years & $0.41(0.16,1.07)$ & 0.068 & - & - \\
\hline $10-20$ years & $0.34(0.13,0.87)$ & 0.02 & - & - \\
\hline $21+($ Ref $)$ & 1.00 & - & - & - \\
\hline \multicolumn{5}{|l|}{ Income } \\
\hline $360-499$ [84.2-116.7] (ref) & 1 & - & 1 & - \\
\hline 500-999 [116.9-233.6] & $1.28(0.50,3.24)$ & 0.610 & $1.37(0.38,4.92)$ & 0.62 \\
\hline $1000-1499$ [233.8-350.5] & $3.79(1.45,9.92)$ & 0.007 & $3.52(0.98,12.64)$ & 0.05 \\
\hline $1500+[350.8]$ & $30.25(3.35,273)$ & 0.002 & $22.63(1.60,320.51)$ & 0.02 \\
\hline \multicolumn{5}{|l|}{ Work structure } \\
\hline Daily paid worker (by day work) (Ref) & 1.00 & - & 1.00 & - \\
\hline Temporal contract workers & $1.24(0.87,1.76)$ & 0.231 & $2.03(1.25,3.31)$ & 0.004 \\
\hline Permanent worker & $4.60(2.68,7.89)$ & 0.001 & $3.97(1.93,8.17)$ & 0.001 \\
\hline \multicolumn{5}{|l|}{ Trade specialization } \\
\hline Mason (ref) & 1 & - & 1 & - \\
\hline Labourer & $1.85(1.27,2.69)$ & 0.001 & $0.77(0.37,1.57)$ & 0.46 \\
\hline Carpenter & $0.46(0.24,0.89)$ & 0.02 & $1.09(0.40,3.00)$ & 0.85 \\
\hline Steel bender & $1.33(0.61,2.89)$ & 0.47 & $0.22(0.07,0.64)$ & 0.01 \\
\hline \multicolumn{5}{|l|}{ Working hours } \\
\hline $4-6 h$ & $0.12(0.05,0.25)$ & 0.001 & $0.05(0.02,0.15)$ & 0.001 \\
\hline $7-9 h$ & $0.23(0.09,0.63)$ & 0.004 & $0.16(0.04,0.36)$ & 0.009 \\
\hline $10+h$ (ref) & 1 & - & 1 & - \\
\hline \multicolumn{5}{|l|}{ Safety instruction } \\
\hline No & $1.27(0.82,1.99)$ & 0.27 & - & - \\
\hline Yes (ref) & 1 & - & - & - \\
\hline \multicolumn{5}{|l|}{ Currently smoking } \\
\hline Never smoked (ref) & 1.00 & - & - & - \\
\hline Currently smokes & $2.41(0.78,7.49)$ & 0.13 & - & - \\
\hline
\end{tabular}


Table 3 (continued)

\begin{tabular}{|c|c|c|c|c|}
\hline \multirow[t]{2}{*}{ Variables } & \multicolumn{2}{|l|}{ Univariate model } & \multicolumn{2}{|l|}{ Multivariate model } \\
\hline & $\begin{array}{l}\text { Crude odd ratio (OR; } 95 \% \\
\mathrm{Cl} \text { ) }\end{array}$ & P-value & $\begin{array}{l}\text { Adjusted odd ratio (aOR; } \\
95 \% \mathrm{Cl} \text { ) }\end{array}$ & P-value \\
\hline \multicolumn{5}{|l|}{ Alcohol consumption } \\
\hline Do not consume (ref) & 1.00 & - & - & - \\
\hline Consume & $1.69(1.13,2.55)$ & 0.010 & - & - \\
\hline \multicolumn{5}{|l|}{ Job/task location } \\
\hline Rooftop & 1 & - & & - \\
\hline Lower floor/ground & $0.22(0.09,0.48)$ & 0.001 & $0.61(0.16,2.31)$ & 0.46 \\
\hline Height from ground & $0.19(0.08,0.45)$ & 0.001 & $0.82(0.21,3.26)$ & 0.78 \\
\hline All location & $0.18(0.80,0.38)$ & 0.001 & $0.29(0.85,1.01)$ & 0.05 \\
\hline \multicolumn{5}{|l|}{ Daily production target } \\
\hline No & 1 & - & - & - \\
\hline Yes & $0.75(0.53,1.05)$ & 0.100 & - & - \\
\hline \multicolumn{5}{|l|}{ Monthly off days } \\
\hline No & 1 & - & - & - \\
\hline Yes & $0.20(0.11,0.38)$ & 0.001 & $0.96(0.04,0.24)$ & 0.001 \\
\hline \multicolumn{5}{|l|}{ Monthly working days } \\
\hline 20 days & 1 & - & - & - \\
\hline 24 days & $0.86(0.54,1.34)$ & 0.496 & - & - \\
\hline 26 days & $0.48(0.15,1.49)$ & 0.203 & - & - \\
\hline 30 days & $2.55(0.51,12.68)$ & 0.252 & - & - \\
\hline
\end{tabular}

Significant values are in italics

\section{Distal factors influencing occupational injuries}

The distal factors predicting occupational injuries describe the organizational and work-related characteristics associated with the injuries. Specifically, the study showed that daily production targets, job location, work structure, trade specialization and off working days influence the risk of occupational injuries among frontline building construction workers. Working continuously without breaks, off-days and vacations predict the risk of injury among construction workers. Our study showed that a worker who enjoys off-days in a month is $96 \%$ protected from injury occurrence compared to those working every day throughout the month. Once a worker engages in continuous work without vacations, holidays and off-days, there is the possibility of fatigue setting in, and when this happens it affects performance and productivity [19]. Therefore, job schedules that offer workers limited opportunities for breaks, off-days, and vacations should be discouraged by managers of the industry.

Working on a permanent basis or as a temporal worker makes a worker more susceptibility to injuries more compared to working daily paid workers. Daily paid workers in the Ghanaian construction industry are normally engaged for relatively short periods, they visit job sites as and when they think they need to work. Such workers are mostly hired to carry out simple task which does not require any special expertise. Permanent workers are likely to experience the cumulative effects of the exposures on their health, unlike the daily paid workers. Finding from our study revealed that, workers operating from all locations and lower grounds were $71 \%$ and $39 \%$ protected from the possible risk of experiencing injury compared to working from a rooftop and elevated ground. This suggests that the chance of slipping from height and its impact on the individual is greater. This corroborates with previous findings from the US, UK, and South Africa which indicated that working from a height and elevation above the ground is the most cited cause of fallrelated injuries [42, 44-46]. The study recommends that policymakers and occupational health experts should incorporate the identified distal factors in the planning and designing of construction projects as part of their injury prevention intervention as well as management strategies. We recommended that further research design with rigorous methods such as a cohort study should be employed to examine the causal relationship between the distal and proximate variables over time. Also, an interventional study is recommended for assessment of the effectiveness of organizational strategies that aim to improve the distal factors facilitating occupational injuries among frontline construction workers. 


\section{Limitation}

The study has limitations in terms of the scope, the target population, data-collection instrument, sampling, and possible recall bias. The study was limited to only construction workers in the Kumasi metropolis without incorporating the perspectives of regulatory bodies and workers in other parts of the country. Also, the instrument used to collect the data was a self-developed questionnaire based on previous literature, theory, and standard injury questionnaire. The study did not adopt any existing validated instrument. Nevertheless, several scientific scrutinies such as pre-testing of tools, random sampling, development of tools using previous literature, informed consent processes, statistical analysis, and discussion of findings in the context of relevant literature were employed to minimize biases.

\section{Abbreviations}

AOR: adjusted odds ratio; Cl: confident interval; GHS: Ghanaian cedis; ODK: Open Data Kit; OR: odds ratio; US \$: United States dollar.

\section{Acknowledgements}

Not applicable.

\section{Authors' contributions}

JA, PAB, EB: conceptualized and designed the study, carried out statistical analysis, write up and preparation of the first draft. EB, EKN, IM: Assisted in the write-up and review of the manuscript. All authors read and approved the final manuscript

\section{Funding}

There was no funding support for this study.

\section{Availability of data and materials}

The datasets used and analyzed for this study are in the custody of the corresponding author and will be made available on a reasonable request.

\section{Ethics approval and consent to participate}

The study was reviewed and approved by the Committee on Human Research Publication and Ethics of the School of Medical Sciences, Kwame Nkrumah University of Science \& Technology, Kumasi. Written informed consent was obtained from all participants enrolled in this study and identities of participants were kept anonymous. Parental consent was sought from minors (below 18 years) who were engaged in an active construction job.

\section{Consent for publication}

Not applicable.

\section{Competing interests}

The authors declare that they have no competing interests.

\section{Author details}

${ }^{1}$ Department of Health Policy, Management and Economics, School of Public Health, Kwame Nkrumah University of Science and Technology, Kumasi, Ghana. ${ }^{2}$ Department of Epidemiology and Biostatics, School of Public Health, Kwame Nkrumah University of Science and Technology, Kumasi, Ghana. ${ }^{3}$ School of Nursing and Midwifery, University of Newcastle, Callaghan, Australia. ${ }^{4}$ Isaac Mensah, Department of Special Education, University of Education, Winneaba, Ghana.

Received: 20 August 2019 Accepted: 17 October 2019

Published online: 06 November 2019

\section{References}

1. Stanaway JD, Afshin A, Gakidou E, et al. Global, regional, and national comparative risk assessment of 84 behavioural, environmental and occupational, and metabolic risks or clusters of risks for 195 countries and territories, 1990-2017: a systematic analysis for the Global Burden of Disease Study 2017. Lancet. 2018;392:1923-94.

2. Collaborators GBD. Global, regional and national levels of age-specific mortality and 240 causes of death, 1990-2013: a systematic analysis for the Global Burden of Disease Study 2013. Lancet. 2015;385:1990-2013.

3. Gyedu A, Nakua EK, Otupiri E, Mock C, Donkor P, Ebel B (2014) Incidence, characteristics and risk factors for household and neighbourhood injury among young children in semiurban Ghana: a population-based household survey. Inj Prev injuryprev-2013-040950.

4. Institute for Health Metrics and Evaluation (2016) Institute for Health Metrics and Evaluation: Ghana.

5. Hämäläinen P, Takala J, Saarela KL. Global estimates of occupational accidents. Saf Sci. 2006;44:137-56

6. Takala J, Hämäläinen $P$, Saarela KL, Yun LY, Manickam K, Jin TW, Heng P, Tjong C, Kheng LG, Lim S. Global estimates of the burden of injury and illness at work in 2012. J Occup Environ Hyg. 2014;11:326-37.

7. International Labour Organization. Statistics of occupational injuries. 1998

8. Suraji A, Duff AR, Peckitt SJ. Development of causal model of construction accident causation. J Constr Eng Manag. 2002. https://doi.org/10.1061/ (asce)0733-9364(2001)127:4(337).

9. Haslam RA, Hide SA, Gibb AGF, Gyi DE, Atkinson S, Pavitt TC, Duff R, Suraji A. Causal factors in construction accidents. Exec: Health Saf; 2003. p. 156.

10. Gibb A, Hide S, Haslam R, Hastings S, Suraji A, Duff AR, Abdelhamid TS, Everett JG. Identifying root causes of construction accidents. J Constr Eng Manag. 2001;127:348-9.

11. Hamid ARA, Majid MZA, Singh B. Causes of accidents at construction sites. Malays J Civ Eng. 2008;20:242-59.

12. Hinze J, Pedersen C, Fredley J. Identifying root causes of construction injuries. J Constr Eng Manag. 1998;124:67-71.

13. Lipscomb HJ, Glazner JE, Bondy J, Guarini K, Lezotte D. Injuries from slips and trips in construction. Appl Ergon. 2006;37:267-74.

14. Toole TM. Construction site safety roles. J Constr Eng Manag. 2002:128:203-10

15. Amissah J, Agyei-Baffour P, Badu E, Agyeman JK, Badu ED. The cost of managing occupational injuries among frontline construction workers in Ghana. Value Heal Reg Issues. 2019;19:104-11.

16. Haagsma JA, Graetz N, Bolliger I, et al. The global burden of injury: incidence, mortality, disability-adjusted life years and time trends from the Global Burden of Disease study 2013. Inj Prev. 2016;22:3-18.

17. Hide S, Atkinson S, Pavitt TC, Haslam R, Gibb AGF, Gyi DE. Causal factors in construction accidents. 2003

18. Suraji A, Duff AR, Peckitt SJ. Development of causal model of construction accident causation. J Constr Eng Manag. 2001;127:337-44.

19. Lombardi DA, Jin K, Courtney TK, Arlinghaus A, Folkard S, Liang Y, Perry MJ. The effects of rest breaks, work shift start time, and sleep on the onset of severe injury among workers in the People's Republic of China. Scand J Work Environ Health. 2014;1:146-55.

20. Ghana Labour Department. Annual Labour report. 2000; 114:286-293.

21. Basu N, Clarke E, Green A, Calys-Tagoe B, Chan L, Dzodzomenyo M, Fobil J, Long RN, Neitzel RL, Obiri S. Integrated assessment of artisanal and smallscale gold mining in Ghana_Part 1: human health review. Int J Environ Res Public Health. 2015;12:5143-76.

22. Afukaar FK, Antwi P, Ofosu-Amaah S. Pattern of road traffic injuries in Ghana: implications for control. Inj Control Saf Promot. 2003;10:69-76.

23. Mock CN, Forjuoh SN, Rivara FP. Epidemiology of transport-related injuries in Ghana. Accid Anal Prev. 1999;31:359-70.

24. EU-OHSA. Musculoskeletal disorders in construction. Eur Agency Saf Health Work. 2015.

25. Laryea S. Health and safety on construction sites in Ghana. 2010.

26. Ghana Statistical Services. Ghana Labour Statistics: Economic activity status of persons 15 years and older by region. 2010.

27. Cochran WG. Sampling techniques. New York: Wiley; 2007.

28. Naing L, Winn T, Rusli BN. Practical issues in calculating the sample size for prevalence studies. Arch Orofac Sci. 2006;1:9-14. 
29. JeffreyCoker F, Basinger M. Open Data Kit: Implications for the Use of Smartphone Software Technology for Questionnaire Studies in International Development. Columbia Univ Mech Eng Dep Available online http//modi mech columbia edu/wp-content/uploads/2010/04/ Open-Data-Kit-Review-Article pdf. 2010. 12. Accessed 1 Jan 2015.

30. Tom-Aba D, Olaleye A, Olayinka AT, et al. Innovative technological approach to ebola virus disease outbreak response in Nigeria using the open data kit and form hub technology. PLoS ONE. 2015;10:e0131000.

31. Bank of Ghana (BOG). Bank Of Ghana Quarterly Statistical Bulletin. Mon. Bull. 2016

32. Adane MM, Gelaye KA, Beyera GK, Sharma HR, Yalew WW. Occupational injuries among building construction workers in Gondar City, Ethiopia. Occup Med Heal Aff. 2013;1:1-5.

33. Australia SW. Work-related injuries and fatalities involving a fall from height. Canberra: Safe Work Australia; 2013.

34. Dement JM. Workers' compensation experience of North Carolina residential construction workers, 1986-1994. Appl Occup Environ Hyg. 1999;14:97-106.

35. Lipscomb HJ, Dement JM, Li L, Nolan J, Patterson D. Work-related injuries in residential and drywall carpentry. Appl Occup Environ Hyg. 2003;18:479-88.

36. Wong T-W. Occupational injuries among construction workers in Hong Kong. Occup Med (Chic III). 1994;44:247-52.

37. Hinze J, Devenport JN, Giang G. Analysis of construction worker injuries that do not result in lost time. J Constr Eng Manag. 2006;132:321-6.

38. Huang $X$, Hinze J. Analysis of construction worker fall accidents. J Constr Eng Manag. 2003;129:262-71.
39. Tessier-Sherman B, Cantley LF, Galusha D, Slade MD, Taiwo OA, Cullen MR. Occupational injury risk by sex in a manufacturing cohort. Occup Env Med. 2014;71:605-10.

40. Choi SD. Safety and ergonomic considerations for an aging workforce in the US construction industry. Work. 2009;33:307-15.

41. De Zwart BCH, Frings-Dresen MHW, Van Duivenbooden JC. Senior workers in the Dutch construction industry: a search for age- related work and health issues. Exp Aging Res. 1999;25:385-91.

42. Schwatka NV, Butler LM, Rosecrance JR. An aging workforce and injury in the construction industry. Epidemiol Rev. 2011;34:156-67.

43. Lemasters GK, Atterbury MR, Booth-Jones AD, Bhattacharya A, OllilaGlenn N, Forrester C, Forst L. Prevalence of work related musculoskeletal disorders in active union carpenters. Occup Environ Med. 1998;55:421-7.

44. Shishlov KS, Schoenfisch AL, Myers DJ, Lipscomb HJ. Non-fatal construction industry fall-related injuries treated in US emergency departments, 1998-2005. Am J Ind Med. 2011;54:128-35.

45. Brabazon P, Tipping A, Jones J. Construction health and safety for the new Millennium. Great Britain: Health and Safety Executive; 2000.

46. McEvoy P. Safety performance on 20 construction sites in Dublin. 2004.

\section{Publisher's Note}

Springer Nature remains neutral with regard to jurisdictional claims in published maps and institutional affiliations.
Ready to submit your research? Choose BMC and benefit from:

- fast, convenient online submission

- thorough peer review by experienced researchers in your field

- rapid publication on acceptance

- support for research data, including large and complex data types

- gold Open Access which fosters wider collaboration and increased citations

- maximum visibility for your research: over 100M website views per year

At BMC, research is always in progress.

Learn more biomedcentral.com/submissions 